\title{
Replacement Windows: New Credit Programs at the Discount Window
}

\author{
David C. Wheelock
}

$\mathrm{T}$ he Federal Reserve lends directly to commercial banks and other depository institutions (hereafter "banks") through its discount window. Such lending helps ensure adequate liquidity in the banking system and serves as a backup source of short-term funding for banks. On January 9, 2003, the Federal Reserve introduced new lending programs designed to better accomplish these functions. The Fed replaced its previous programs, "adjustment" and "extended" credit, with "primary" and "secondary" credit programs. (The "seasonal" credit program remains unchanged.) The new programs differ from their predecessors in several respects, the most significant of which are (i) that the interest rates charged for primary and secondary credit are set above the prevailing rate for federal funds and (ii) that banks ordinarily face few, if any, restrictions on their use of primary credit. ${ }^{1}$

Traditionally, the Fed's discount rate was set below the market rate for federal funds. The volume of outstanding discount loans was ordinarily small, however, because the Federal Reserve prohibited banks from using discount window loans to finance sales of federal funds or for otherwise expanding their assets. Banks also were thought to be reluctant to borrow from the discount window because of a stigma associated with such borrowing. The chart shows the levels of the discount rate and market federal funds rate, as well as discount window borrowing as a percentage of total reserves, for 1987-2002. Except for a brief surge in borrowing after September 11, 2001, discount loans rarely exceeded 1 percent of total banking system reserves in these years, even though the discount rate was almost always less than the funds rate.

In contrast to adjustment and extended credit, primary credit may be used for any purpose, including financing the sale of federal funds, and banks are no longer required to seek funds from alternative sources before requesting a discount window loan. Primary credit, however, is available only to sound banks-generally those with adequate capital and supervisory ratings for safety and soundness (i.e., CAMELS composite ratings of 1,2 , or 3 ). Secondary credit is intended for banks that are not eligible for primary credit, and may not be used to fund an expansion of a bank's assets.
The primary credit lending rate is set above the Federal Open Market Committee's target federal funds rate, and the secondary credit rate is set above the primary credit rate. Thus, the discount window should serve only as a backup source of funds for banks, as sound banks ordinarily will choose to obtain short-term funds less expensively from the federal funds market or other market sources. Indeed, the primary credit rate is expected to cap the market funds rate. By introducing a separate lending program for sound banks and imposing few restrictions on the use of primary credit, however, the Fed has likely minimized banks' reluctance to borrow from the discount window. Hence, the new credit programs are expected to ensure that funding is readily available at the primary credit rate in the event of a temporary shortage of liquidity in the banking system.

\footnotetext{
${ }^{1}$ For additional details about the programs, see www.frbdiscountwindow.org.
}

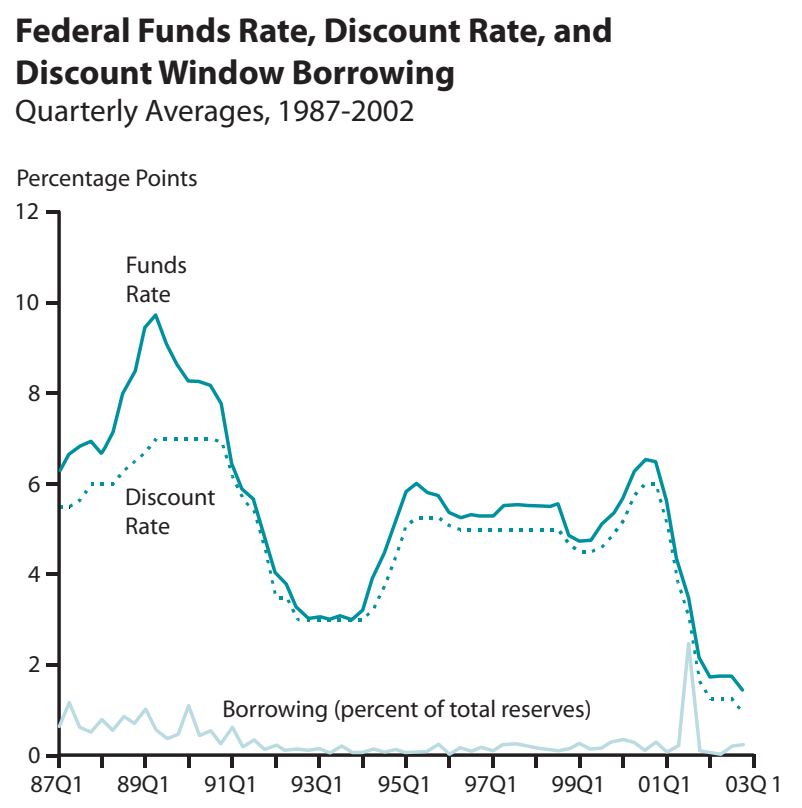

